\title{
Sistema é a Bomba e o Pavio - O projeto da Literatura Marginal/Periférica revisto a partir dos Coletivos Poesia na Brasa e Perifatividade em São Paulo.
}

\section{Silvio Rogério dos Santos*, Mário Augusto Medeiros da Silva e Taniele Crisitina Rui (Coorientadora)}

\begin{abstract}
Resumo
O projeto em questão busca dar sequência ao projeto anterior, de discutir como são interpretadas e mobilizadas as proposições levantadas pelos coletivos literários da periferia nos tempos atuais, comparando-as com as propostas de seu surgimento, no começo dos anos 2000. Dessa forma, foi priorizado o tratamento do material acumulado até então, como as entrevistas, o caderno de campo e os demais materiais acumulados durante a pesquisa realizada com os Coletivos Poesia na Brasa e Perifatividade. Objetiva-se reconstituir analiticamente aspectos das histórias e formas de organização, como também dar continuidade à observação participante das ações desenvolvidas por estes grupos, no intuito de conseguir uma compreensão mais substancial desse fenômeno.
\end{abstract}

\section{Palavras-chave:}

Literatura Marginal/Periférica, Periferia, Movimentos Culturais.

\section{Introdução}

Os últimos quinze anos consolidaram a produção cultural das periferias na cidade de São Paulo, a partir do surgimento de sua produção literária. Se tal região era conhecida por ser reduto da criminalidade e da violência, com a proliferação dos saraus promovidos pelos coletivos literários das periferias a história tem sido outra. A produção literária das periferias, mais conhecida por "Literatura Marginal" ou "Literatura Periférica", ao pôr em evidência o cotidiano dos moradores das regiões mais afastadas da cidade e carentes tanto de políticas públicas como de direitos sociais, tem conduzido as interpretações sobre as periferias e seus habitantes a outros patamares. Aliando a apropriação da leitura e da escrita com a identidade cultural e política das periferias, ativistas culturais estão transformando aquilo que significa "ser da periferia". Para além de sua produção cultural, esses atores sociais também estão impactando o próprio fazer político da cidade, mobilizando conhecimentos, direitos e agências através de sua mobilização, causando reflexões e ações que colocam em pauta não só o direito a cidade e aos bens culturais e sociais, mas a própria efetividade da cidadania e democracia brasileira. A partir do lugar que essa produção cultural ocupa atualmente dentro da cidade de São Paulo e ao longo dos anos, este projeto busca entender não só como se dá a relação entre os coletivos e o poder público, mas também o que ficou/fica, dessa produção nas periferias.

\section{Resultados e Discussão}

Dando sequência ao projeto, deu-se início ao tratamento do material colhido ao longo do primeiro ano de pesquisa. Tal material é composto pelos relatórios de campo, de um pequeno material audiovisual e principalmente pelas oito entrevistas realizadas com integrantes dos coletivos Perifatividade e Poesia na Brasa. Cabe citar que, das oito entrevistas realizadas, três foram realizadas durante essa segunda parte do projeto. A bibliografia acerca do tema também foi atualizada, tal qual os relatórios de campo, sobre as atividades dos coletivos. Ainda que não conseguindo tratar todo o material colhido, este projeto buscou entender - à partir do lugar que a produção cultural das periferias ocupa atualmente na cidade de São Paulo e ao longo dos anos - não só como se dá a relação entre os coletivos e o poder público, mas também o que ficou/fica, dessa produção nas periferias.

\section{Conclusões}

Os coletivos literários das periferias se constituíram como uma força popular importante não só em seus locais de atuação, mas também na cidade de São Paulo. Apesar de partilharem de pressupostos comuns, tais coletivos são heterogêneos e mobilizam diversas questões, conflitos e contradições, comuns a quaisquer mobilizações sociais. O financiamento das atividades destes grupos através de políticas públicas ou da iniciativa privada, tem colocado várias questões na ordem do dia. Tal relação ainda permeia discussões sobre o papel dessa produção cultural no contexto das desigualdades sociais, principalmente no momento histórico de retrocessos que estamos vivendo.

\section{Agradecimentos}

Agradeço especialmente a meu orientador, Prof. Dr. Mário Augusto Medeiros e minha co-orientadora, Prof. ${ }^{a}$ Dr. ${ }^{\text {a }}$ Taniele Rui, pelo apoio, confiança, sinceridade, parceria e troca, sem os quais esse projeto não existiria. Agradeço enormemente aos interlocutores da pesquisa (Coletivo Perifatividade e Coletivo Poesia na Brasa). Agradeço minha mãe e meus irmãos, assim como meus amigos e amigas, tão fundamentais em minha vida, tal como nesse processo.

D'ANDREA, Tiarajú Pablo. A formação dos sujeitos periféricos: cultura e política na periferia de São Paulo. 2013. Tese (Doutorado em Sociologia) Faculdade de Filosofia, Letras e Ciências Humanas, Universidade de São Paulo, São Paulo, 2013. Disponível em: <http://www.teses.usp.br/teses/disponiveis/8/8132/tde-18062013-095304/>. Acesso em: 2018-01-15

DE TOMMASI, Lívia. Culturas de Periferia: entre o mercado, os dispositivos de gestão e o agir político. Política e Sociedade, Florianópolis, vol. 12, pp. 1134, 2013.

NASCIMENTO, Érica Peçanha do. Vozes Marginais na Literatura. Rio de Janeiro: Aeroplano, 2009.

SILVA, Mário Augusto Medeiros da. A Descoberta do Insólito: Literatura Negra e Literatura Periférica no Brasil (1960-2000). Rio de Janeiro: Aeroplano, 2013. 